\title{
The Impact of FDI on the Structure of the Kosovo Economy
}

\author{
PhD. Nakije Miftar Kida \\ College AAB, Pristina, Albania
}

\begin{abstract}
This study has addressed the impact of domestic investment and FDI net flow from the services sector on economic growth for a period of 10 years. The data are taken from CBK, in annual periods, using the technique of Pearson correlation and multiple OLS regression, conducted with the statistical program SPSS 21.0. FDI attraction by the services sector is found to be greater than by the other sectors. This becomes more evident by findings from econometric analysis, where the services sector has a strong impact on economic growth in the country. Meanwhile, the "crowding out" effect has happened, indicating that local investment (local firms) has a modest level of technical and managerial changes, since increasing effect is estimated to be negative. According to this study, the economy of Kosovo has grown with an average rate of $4 \%$ for 16 years and the biggest contributor is the services sector with $56 \%$ of GDP, which includes financial services, insurance companies, construction, telecommunications, real estate, trade etc. This pace still continues to be a model of economic growth in Kosovo and continues to be supported by certain economic policies, while other sectors lag behind. This result clearly shows that, although the level of FDI inflows in Kosovo is low, the sector specification shows positive trend of incoming flows in the services sector. This is due to dominance in market of the financial sector and that of insurance with foreign capital as the only financing source of the local businesses.
\end{abstract}

Keywords: FDI, GDP growth rate, Domestic investment, Services sectors, Kosovo.

\section{Introduction}

Perceptions about Foreign Direct Investment (FDI), for over half a century have mostly varied, never reaching a common consensus on the impact, effects and their role in economic growth. FDI is considered as the main driver of economic growth in the last three decades and today it is considered as one of the most actual topics. Economic growth represents the rate to which the real GDP increases; it is the basis for meeting the increasing needs of people. The IMF defines the foreign investment as "direct" when an investor holds $10 \%$ or more of the assets of an enterprise abroad, enough to give the investor a measure of control over its management. FDI is permitted through financial partnership, private equity and joint venture. Even the FDI contribution towards economic and industrial development of Kosovo has been less important.FDI in Kosovo, though increased for about seven times from 440.7 million euros in 2007, which is also the FDI peak for 17 years in Kosovo, to 151.7 million euros in 2014, whereas 308.8 million euros in 2015, and 2016 brought only 215.9 million euros, or for 10 years in total 3.036 .1 million euros, it has failed to meet the capital, technology and knowledge gap, furthermore the growth of population welfare. Although it continues to be a cost-competitive country for FDI in the manufacturing, mining, electricity and low wages sectors, it has failed to attract serious investors. The services sector in Kosovo (the banking, insurance, real estate, tourism and commerce sector) has benefited the most. Successful banks are commercial banks Pro Credit Bank or PCB by the merger of international companies, Raiffeisen Bank or RBKO from Austria, Bank of Ljubljana or NLB from Slovenia, National Commercial Bank. Contribution to economic growth is attributed to these sectors helped by consumption, remittances and too little by exports. 


\section{The purpose of the study}

The purpose of this study is providing answers to research questions related to the impact of FDI, services sector and local investment on economic growth in Kosovo.

This study aims the following objectives:

- To study the trends of FDI flow (descriptive analysis);

- To rate the effect of FDI net inflows, services and domestic investment sector on economic growth (through multiple regression and Pearson correlation);

\section{Reference resources}

This paper is based on secondary sources for the period 2007-2016. The main sources of data are from Kosovo Agency of Statistics (KAS), Central Bank of Kosovo (CBK).

\section{Methodology followed to conduct the study}

Since the study deals with the FDI issue in the theoretical aspect, there has been used the meritorious (methodology) that treats the impact of FDI on economic growth seeing the relation between them and its determinants. To explain the empirical research these tools have been used:

- The secondary quantitative data were collected mainly through the time series of the World Bank. Variables were found in relation to GDP as standard in the literature.

-SPSS program has served for statistical processing of study data.

-The technique of the least squares or ordinary least squares (OLS) is used.

Used methods and models are:

- Descriptive presentation, through description of questionnaires, assessments have been made as part of the conclusions.

- The technique of multiple regression, Pearson and Spearman correlation.

OLS model (Ordinary Least Squares) by the following equation:

$\log \_2 G D P g p c_{i t}=a_{0 i t}+\beta_{1} \log 2 \_F D I s e r v . s e c t 0_{i t}+\beta_{2} \log 2 \_D o m . I n v_{i t}++\varepsilon_{i t} \ldots . . . e q .(1)$

GDPgpc= Annual GDP growth rate per capita; FDI= Foreign Direct Investment \% GDP; Do.Inv.= Domestic Investment \% GDP; $\varepsilon$ it $=$ Standard error

Multiple regression analysis has been used to identify major variables (determinants) that have impact on FDI and economic growth. The coefficient of determination $\mathrm{R}^{2}$ (Brown, 2007), Durbin - Watson statistics [D-W], standard error of coefficients, t-statistics, F - ratio, and other important econometric tests have been conducted to evaluate the relative importance and credibility of evaluation of model parameters.

Research questions: How has the FDI net inflow, from local services and investment sector, influenced on the growth of GDP per capita in Kosovo?

Hypothesis: FDI and local investment in Kosovo positively affect the growth of GDP per capita.

\section{Possibilities and Limitations}

The study focus is to verify whether Foreign Direct Investment has contributed towards economic growth in Kosovo, and how much FDI other determinants have attracted in the period covering the years 2007-2016.

Apart from the contribution that this study offers, there are limitations: 
- The sample size in the secondary data has not included a wide range of variables.

\section{Importance of Study}

Kosovo lacks capital, and this capital can be more easily collected if the country has advancement in the use of technology and knowledge (which are hardly measured in Kosovo). If the selected variables in the study as determinants of FDI and economic growth are positive or negative, but not zero, then it is an important prognosis to guide government policies pro or against these macroeconomic variables. It is also important to become familiar with the local investment, to find obstacles and opportunities to advance, though modest, the technology and management of human resources. However, the importance of this study is to increase the time horizon of the study compared with the previous ones.

\section{Overview of Literature}

This section presents different views on the impact of FDI and other determinants on economic growth, summarizing the arguments and counter arguments based on theory and empirical evidence. Literature offers no clear predictions about the FDI effects on economic growth and development. Providing conditions for FDI expectation by the host country must be one of the main activities as investment incentives, their promotion, etc. Through their control, foreign investors achieve the goals, but despite their interests for profit, FDls in developing countries bring new managerial techniques, training, capital, create new jobs, higher salaries, improved employment conditions, and development of industrial sectors. Analysis of the theories of commercial activities with abroad on both macro and micro levels, and in particular the Dunning "OLI" theory have dealt and continue to deal with the issue of FDI (the most actual phenomenon of 20th century). Neoclassical theory predicts increasing the availability of capital per capita instead of maximizing the growth of FDI. Economic growth is associated with significant fluctuations of relative sizes of economy sectors. Authors and relevant institutions such as Chenery and Strout (1996), Dunning (1970), Todaro (1982), Kruger (1987) and World Bank (1993), prove that FDI continuously promote growth of GDP. Neoclassicists point out that savings, i.e. accumulation of capital is the main engine of economic growth. Supporters of this economic theory who have worked in that field like; Reuber (1973); Kojima (1978), Bergten, et al. (1978); Chu (1989); Antonelli (1991); Kennedy (1992); Lall (1993); Sornarajah (1994); Seid (2002), Narula (argued that FDI increase competition and improve productivity. This advantage of competition will lead to better resource allocation, better capital exploitation, efficient management and efficiency increase in the market. However, the empirical literature has left behind (there is not a consensus reached yet) and there were a lot of problems to identify advantages in practice.

\section{Data analysis and study results}

The descriptive analysis in table 1 is conducted to examine the trend of FDI inflows, their origin and structure in the global economy and in Kosovo. This study in particular includes the FDI determinants in Kosovo, emphasizing the investment period since liberalization of the economy (1999-2014) until now. This chapter focuses on three issues:

$\checkmark$ Firstly, it deals with descriptive analysis (Jaagi. S,. 2003:1-18), of FDI statistics according to the structure of the economy; $\checkmark$ Secondly, of great interest is the impact of determinants of GDP growth such as FDI from the services sector and local investment with conclusive analysis of regression and correlation.

First, the model concludes that the values of the variable logarithm of annual GDP growth per capita (log_2GDPgro.pc) on average are more concentrated than other variables because the distribution of values is 1:39 units from average 3:28 units, this distribution is the lowest. 
Table 1: Descriptive Statistics from the time series (author's work, data from CBK-time series 2007-1016).

\begin{tabular}{|l|l|l|l|l|}
\hline \multicolumn{2}{|l|}{} & $\begin{array}{l}\text { Log2_GDPgpc\% } \\
\text { annual }\end{array}$ & Log2_Domestic Investment \%GDP & $\begin{array}{l}\text { Log2_IHD- services sector } \\
\text { \%GDP }\end{array}$ \\
\hline $\mathrm{N}$ & Valid & 10 & 10 & 10 \\
\hline MA (Mean) & 3.28720675730 & 3.774187772 E8 & 6.98536020570 \\
\hline DS (Std.Deviation) & 1.397918487361 & 1.7964851405 E8 & 3.374697562467 \\
\hline
\end{tabular}

Source: CBK, 2016, time series, author's work

The second best variable from distribution, after the annual GDP growth per capita, is the logarithm of domestic investment having an average of 3.77 units with a distribution from an average of 1.79 units, indicating that even in this case the distribution is concentrated during our period of analysis. At the Foreign Direct Investment, the services sector (FDI services sectors), the distribution of values is 3:37 units from average of 6.98 units. This indicates that these variables have concentrated distribution throughout the analysis period (2007-2016).

Dependent variable:Log2_Annual GDP growth per capita. Independent variables:Log2_Domestic Investment \% GDP and Log2_FDI services sector \% GDP.

Table 2, the value $\mathrm{R}$ represents the multiple correlations and it is .802 which shows a high degree of correlation. The value $R^{2}$ ( "R Square) is the Fraction of total variation which is explained by regression; $R^{2}$ is a measure of the explanatory power of the model which shows how far the variance of dependent variable can be explained, in our case - annual GDP growth per capita - with independent variable, domestic investment and FDI in the services sector in the period 2007-2016. In this case, $64.3 \%$ can be explained, which is very high.

Table 2: Model Summaryb

\begin{tabular}{|l|l|l|l|l|l|}
\hline Model & $R$ & $R$ Square $\left(R^{2}\right)$ & Adjusted R Square & Std. Error of the Estimate & Durbin-Watson \\
\hline 1 & $.802^{\mathrm{a}}$ & .643 & .541 & .947080225853 & 2.443 \\
\hline
\end{tabular}

a. Predictors: (Constant), 2LogFDI- entries in the services sector for the years 2004-2016, expressed in \%GDP, 2Log Domestic Investment. b. Dependent Variable: log2 Annual growth of GDP per capita

Table 3: ANOVAb

\begin{tabular}{|l|l|l|l|l|}
\hline Sum of Squares & Df & Mean Square & F & Sig. \\
\hline 11.309 & 2 & 5.654 & 6.304 & $027^{\mathrm{a}}$ \\
6.279 & 7 & .897 & & \\
17.588 & 9 & & & \\
\hline
\end{tabular}

a. Predictors: Predictors: (Constant), 2LogFDI- entries in the services sector for the years 2004-2016, expressed in \%GDP, 2Log Domestic Investment.

\section{b. Dependent Variable: log2Annual GDP growth per capita}

Tablel 3, is ANOVA, which reports how well the regression equation fits the data (ie, predicts the dependent variable). This table shows that regression model predicts the dependent variable in statistically significant way. See the "regression" line and see the value of "Sig." which shows the statistical significance of the regression model. In our case, $p=.027^{a}$ is less than 0,05 , and shows that the regression model statistically predicts result. 
Table 4 :Coefficients ${ }^{\mathrm{a}}$

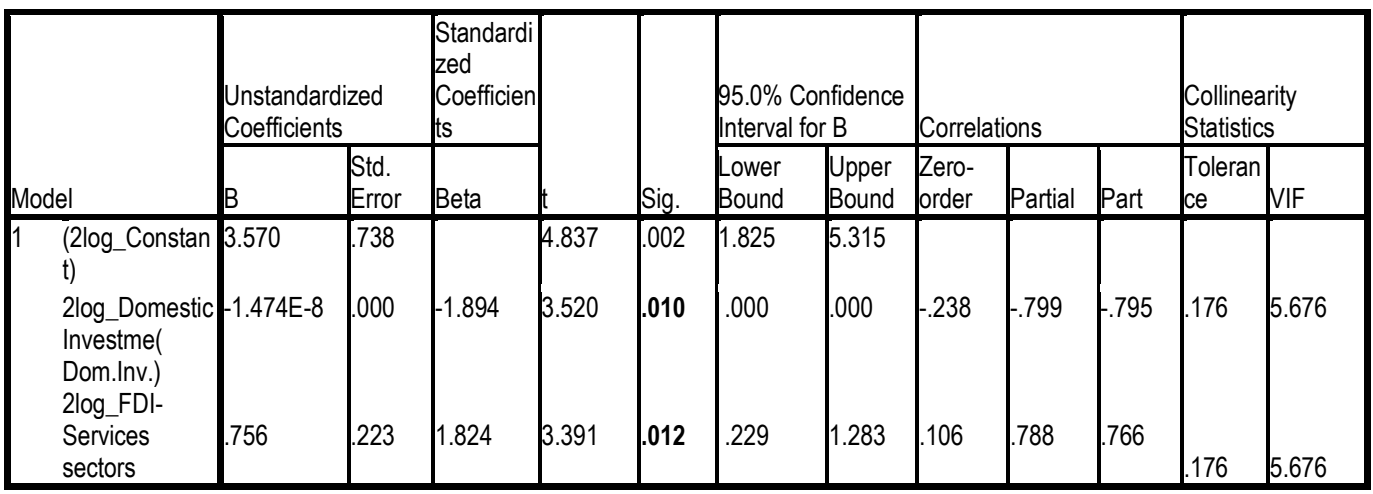

a)Dependent Variable: log2_Annual GDP growth per capita. (Source: CBK, 2016, time series, author's work).

Table 4, "Coefficients" provides the necessary information to predict log2_Annual GDP growth per capita from independent variables 2log_FDI services sector and 2log_Domestic Investment for the years 2004-2013, to determine whether GDP growth per capita has contributed to the statistical model (looking at "Sig."). Moreover, we can use the values in the "B" column under the "Unstandardized Coefficients" column, as shown below, to present the regression equation: Annual growth of GDPgpc $=\mathrm{C}_{0}-2 \log$ Domestic Investment $+2 \log F D I$ services sector

Log2_GDPgpc= $3.507-1.47+0.75$

Table 5: Correlations (Source: CBK, 2016, time series, author's work).

\begin{tabular}{|l|l|l|l|}
\hline Pearson Correlation & GDPgpc, annual \% & Dom.Inv. \% GDP & FDI sec.r ser. \%GDP \\
\hline Log2_GDPgpc \% & 1.000 & -.238 & .106 \\
Log2_Dom.Inv \%GDP & -.238 & 1.000 & .908 \\
Log2_FDI services sector \%GDP & .106 & .908 & 1.000 \\
\hline Sig (1 -tailed) Log2_GDPgpc, &. & .254 & .386 \\
Log2_Do.Inv & .254 &. & $.000^{*}$ \\
FDI services sector & $.386^{* *}$ & $.000^{*}$ &. \\
\hline N & 10 & 10 & 10 \\
& 10 & 10 & 10 \\
& 10 & 10 & 10 \\
\hline
\end{tabular}

*. Correlation is significant at the 0.05 level (1-tailed).

**. Correlation is significant at the 0.01 level (1-tailed).

I.e. Domestic Investments have had a negative impact on economic growth due to the "Crowding-out" effect, while the FDI services sector measured at time delay 2 log has contributed to annual GDP growth per capita in Kosovo.

Whereas Table 5 presents the correlation between three variables and this relationship is strong positive $p=000<0.05$ between FDI services sector and local investment, the link is also positive $0.386^{*}$ between FDI-services sector and economic growth and too important $p=0.012>0.05$. Meanwhile the relation between economic growth and local investment is important and negative $-.238^{\star}$.

Table 6 also presents and diagnoses collinearity between variables. 
Table 6:Collinearity Diagnostic ${ }^{a}$

\begin{tabular}{|c|c|c|c|c|c|}
\hline \multirow{2}{*}{$\begin{array}{l}\text { Model } \\
\text { Dimension }\end{array}$} & \multirow[t]{2}{*}{ Eigenvalue } & \multirow[t]{2}{*}{ Condition Index } & \multicolumn{3}{|c|}{ Variance Proportion } \\
\hline & & & Constant & $\begin{array}{l}\text { Domestic Investment } \\
\% \text { GDP }\end{array}$ & $\begin{array}{l}\text { FDI-services sector \% } \\
\text { GDP }\end{array}$ \\
\hline $\begin{array}{l}11 \\
2 \\
3\end{array}$ & $\begin{array}{l}2.870 \\
.114 \\
016\end{array}$ & $\begin{array}{l}1.000 \\
5.018 \\
13.464\end{array}$ & $\begin{array}{l}.02 \\
.98 \\
.00\end{array}$ & $\begin{array}{l}.00 \\
.04 \\
.96\end{array}$ & $\begin{array}{l}.00 \\
.05 \\
.95\end{array}$ \\
\hline
\end{tabular}

Source: CBK, 2016, time series, author's work.

\section{Conclusion}

This paper issued; as a finding the FDI effect from the services sector and local investment in the growth rate of GDP per capita (all variables have been measured with a time lag of two years -log2. The results show that the lack of impact of local investments on growth depends on technology and its modest management in local companies and competition from foreign firms. The "crowding-out" effect on local investment proves such a thing. A powerful finding in the model is considered the positive effect of attracting foreign investment by the services sector, considered to dominate in Kosovo. We have found that the statistical explanatory power of the independent variables included in explaining the changes in the dependent variable, the rate of GDP growth per capita exceeds 64.3 percent, as shown by the $\mathrm{R}^{2}$ values. We also say that Durbin Watson turns out to have no autocorrelation problems. So the statistical significance of results obtained by regressions is good. Since the research covers the period 2007 - 2016, the outcome with the OLS method has shown that at domestic investment $\left(\beta_{1}=-1.47\right)$ is presented the negative effect on economic growth or the phenomenon of "Crowdingout" effect mentioned above, while the FDI services sector $\left(\beta_{2}=0.75\right)$ seems to have a positive impact on growth, but this relation is distributed positively even between local investments through partnership. Therefore it should be focused on improving the capital performance and management of the local businesses to catch the "spillovers effects" of foreign firms, so that the local firms become more competitive. The government should try to promote transparency in all macroeconomic issues in sectors of the economy. The policies in the country should aim at macroeconomic, institutional and political stability to make the country more attractive to foreign investors. The country's performance in terms of GDP, is an important factor to promote investor's confidence, the government must find ways to promote local production.

\section{References}

[1] Agosin, M. \& Machado, R. (2005) Foreign investment in developing countries: Does it crowd in domesticinvestment? Oxford Development Studies, 33(2), pp. 149-162.

[2] Abdul Khaliq., Ilan Noy (2007). Foreign Direct Investment and EconomicGrowth: Empirical Evidence from Sectoral Data in Indonesia.pp.1-28. http://www.economics.hawaii.edu/research/workingpapers/WP_07-26.pdf

[3] Alfaro, L. (2003). Foreign Direct Investment and Growth:Does the SectorMatter? *Harvard Business School.pp.2-3. http://www.people.hbs.edu/lalfaro/fdisectorial.pdf

[4] Blomstrom, M. (1991). Host Country Benefits of foreign investment. NBR Working Paper 3615, pp 1-33.

[5] Borensztein E., J. De Gregorio and Lee J W (1997). How does foreign direct investment affect economic growth? Journal of International Economics 45 (1998), pp 115-135.

[6] Cantwell, J. and Narula, R. (2001) The eclectic paradigm in the global economy, International Journal.of the Economics of Business, 8 (2), pp. 155-172..

[7] De Mello LR (1997). Foreign Direct Investment in Developing Countries and Growth: A Survey selection. Journal of Development Studies 34 (1), pp 1-34.

[8] Dunning. John H. (2006). Towards a new paradigm of development:implications for the determinants ofinternational business.pp.1-55.http://unctad.org/en/docs/iteiit20061a7_en.pdf

[9] Kida N., (2013).FDI and GDP fluctuations in Kosovo to attract FDI from the particular sector of economy.pp.1IJAS- International Journal of Arts and Scienced, Conference, 3-6, Decembar 2013. International Journal of 
Business and Management Studies (IJBMS), Vol. 3, No. 1. pg.151-155(2014).

http://www.internationaljournal.org/freiburg.htmhtt

[10] Massoud N. (2008). 'FDI and Growth in Emerging Markets: Does the Sectoral Distribution Matter - The Case of Egypt' .pp.1-39. Emerging Markets Group CassBusiness School City University 106 Bunhill Row London EC1Y 8TZ UK, https://www.cass.city.ac.uk/_data/assets/pdf_file/0009/76257/Massoud_08.pdf

[11] Jaagi, S., (2007). Descriptive Statistics and exploratory data analysis.pp.118.http://www.iasri.res.in/ebook/EB_SMAR/e-book_pdf\%20files/Manual\%20II/1-Descriptive\%20Statistics.pdf

[12] Buletini Mujor Statistikor 2017 / N.18 6.pp.1-151. http://bqkkos.org/repository/docs/2015/BQK_BMS_186_al.pdf

[13] Sistemi Financiare informata mujore. 02. Janar 2017.pdf http://www.bqkkos.org/repository/docs/2015/02.\%20FINALI_SISTEMI\%20FINANCIAR_Janar\%202017

[14] Raporti I Stabilitetit Financiare. Nr.10. dhjetor 2016. Pp.1-114. http://bqkkos.org/repository/docs/2015/02.\%20BQK_RSF\%20-\%2010.pdf 